\title{
RECENT RESEARCH ON THE GROWTH PLATE Recent insights into the regulation of the growth plate
}

\author{
Julian C Lui ${ }^{1}$, Ola Nilsson ${ }^{1,2}$ and Jeffrey Baron ${ }^{1}$ \\ ${ }^{1}$ Program in Developmental Endocrinology and Genetics, Eunice Kennedy Shriver National Institute of Child Health \\ and Human Development, National Institutes of Health, CRC, Room 1-3330, 10 Center Drive, MSC 1103, \\ Bethesda, Maryland 20892-1103, USA \\ ${ }^{2}$ Center for Molecular Medicine and Pediatric Endocrinology Unit, Department of Women's and Children's Health, \\ Karolinska Institutet and Karolinska University Hospital, SE-171 76 Stockholm, Sweden
}

Correspondence should be addressed to J C Lui

Email

luichunk@mail.nih.gov

\begin{abstract}
For most bones, elongation is driven primarily by chondrogenesis at the growth plates. This process results from chondrocyte proliferation, hypertrophy, and extracellular matrix secretion, and it is carefully orchestrated by complex networks of local paracrine factors and modulated by endocrine factors. We review here recent advances in the understanding of growth plate physiology. These advances include new approaches to study expression patterns of large numbers of genes in the growth plate, using microdissection followed by microarray. This approach has been combined with genome-wide association studies to provide insights into the regulation of the human growth plate. We also review recent studies elucidating the roles of bone morphogenetic proteins, fibroblast growth factors, C-type natriuretic peptide, and suppressor of cytokine signaling in the local regulation of growth plate chondrogenesis and longitudinal bone growth.
\end{abstract}
Key Words
- growth hormone
- signal transduction
- IGF
- microarray
- skeletal

\section{Introduction}

In the postnatal mammal, elongation of tubular bones occurs at the growth plate. This cartilaginous structure comprises three zones that contain chondrocytes at different stages of differentiation (Kronenberg 2003). The zone closest to the epiphysis is termed the resting zone. The resting zone is thought to contain chondrocytes that serve as progenitor cells, which can generate new clones of rapidly proliferating chondrocytes (Abad et al. 2002). Each derivative clone forms a cell column aligned parallel to the long axis of the bone. As these cells replicate, the two daughters line up parallel to the long axis to maintain the columnar organization. The chondrocytes farther from the epiphysis undergo termination differentiation, in which they cease proliferating and enlarge to form the hypertrophic zone. Throughout the growth plate, chondrocytes secrete proteins and proteoglycans that form the cartilage extracellular matrix. In the resting and proliferative zones, collagen II represents a major component of this matrix, whereas in the hypertrophic zone, there is a shift to production of collagen $\mathrm{X}$ (Kronenberg 2003). The hypertrophic chondrocytes farthest from the epiphysis undergo cell death. This cell death has been attributed to apoptosis, but more recent evidence challenges this conclusion (Emons et al. 2009). This region is then invaded from the metaphyseal bone by blood vessels and differentiating osteoblasts and osteoclasts, which remodel the cartilage into bone tissue. The net result of this chondrogenesis and ossification is the formation of new bone underneath the growth plate and therefore bone elongation. 
The integrated processes of chondrocyte differentiation, proliferation, cartilage matrix secretion, cell death, and vascular and bone cell invasion are regulated and coordinated by a complex array of paracrine signaling molecules, which includes insulin-like growth factors (IGFs), fibroblast growth factors (FGFs), Indian hedgehog (IHH) and parathyroid hormone-related protein (PTHrP), bone morphogenetic proteins (BMPs), WNTs, and vascular endothelial growth factors (VEGFs). In addition, the rate of endochondral bone formation at the growth plate is regulated by an array of endocrine signals, including growth hormone $(\mathrm{GH})$, IGF1, thyroid hormone, glucocorticoids, androgens, and estrogens. One of the principal apparent functions of this endocrine system is to allow rapid growth only when the organism is able to consume abundant nutrients.

Because the growth plate requires so many paracrine and endocrine signaling pathways to function normally, mutations in many genes involved in these signaling pathways lead to bones that are short, which in humans presents as short stature, and often malformed, which presents as a skeletal dysplasia. Thus, mutations in more than 200 genes cause distinct skeletal dysplasias (Warman et al. 2011).

Although there has been remarkable progress recently in our understanding of these signaling pathways that regulate the postnatal growth plate, much remains to be learned. In this review, we present some recent studies giving new insights into these control systems. The number of studies to be reviewed had to be limited, and therefore not all important areas of progress could be included.

\section{Delineating gene expression patterns in the mammalian postnatal growth plate}

In the past, gene expression within the growth plate has typically been studied by in situ hybridization, which provides much useful information but necessarily involves studying one candidate gene at a time. However, recently, methods have been developed to study expression patterns of large numbers of genes in the growth plate, using microdissection, followed by microarray analysis (Nilsson et al. 2007). Frozen sections of the growth plate are first microdissected into their constituent zones after which RNA is isolated and mRNA patterns are assessed by microarray analysis. Presumably, the method could readily be modified to use RNA sequencing in place of microarray analysis.

This approach was applied to the proximal tibiae of 1-week-old rats and the resulting expression data were analyzed using bioinformatic algorithms (Lui et al. 2010). Expression in the resting and the proliferative zones were compared to identify pathways involved in the differentiation of resting zone to proliferative zone chondrocytes. This analysis implicated vitamin D receptor/retinoid X receptor (VDR/RXR) activation, plateletderived growth factor (PDGF) signaling, BMP signaling, and notch signaling. Similar analyses of the proliferative to hypertrophic differentiation step implicated p53 signaling, ephrin receptor signaling, oncostatin M signaling, and BMP signaling (Lui et al. 2010).

\section{Evidence for a BMP signaling gradient across the growth plate}

As noted above, microarray analysis implicated BMP signaling in both the differentiation of resting zone chondrocytes to proliferative zone chondrocytes and of proliferative zone chondrocytes to hypertrophic zone chondrocytes. More extensive analysis of the BMP signaling pathway using microdissection followed by real-time PCR has shown evidence for a BMP signaling gradient across the growth plate with the greatest BMP signaling occurring in the hypertrophic zone and the least in the resting zone (Nilsson et al. 2007). Consistent with this concept, immunolocalization of phosphorylated SMAD1, SMAD5, and SMAD8 in the growth plate increases with increasing distance from the epiphysis (Yoon et al. 2006).

These patterns indicate that a BMP signaling gradient across the growth plate may contribute to the progressive differentiation of resting to proliferative to hypertrophic chondrocytes (Fig. 1). Low levels of BMP signaling in the resting zone may help maintain the progenitor cell state. Farther from the epiphysis, greater BMP signaling may induce differentiation to proliferative chondrocytes and, even farther from the epiphysis, yet greater BMP signaling may induce terminal differentiation to hypertrophic chondrocytes. Functional studies support this model. BMP2 stimulates resting zone chondrocytes to proliferate and stimulates proliferative zone chondrocytes to hypertrophy in an organ culture model (De Luca et al. 2001). In vivo overexpression of constitutively active Bmpr1a in mice has no effect on proliferation but accelerates hypertrophic differentiation (Kobayashi et al. 2005). Recent evidence specifically implicates $B m p 2$ in this process. In mice, conditional targeted ablation of $B m p 2$ causes severe defects in chondrocyte proliferation and differentiation through a mechanism involving RUNX2 protein levels (Shu et al. 2011). The effects of BMPs on the growth plate appear to involve the canonical BMP

Published by Bioscientifica Ltd 


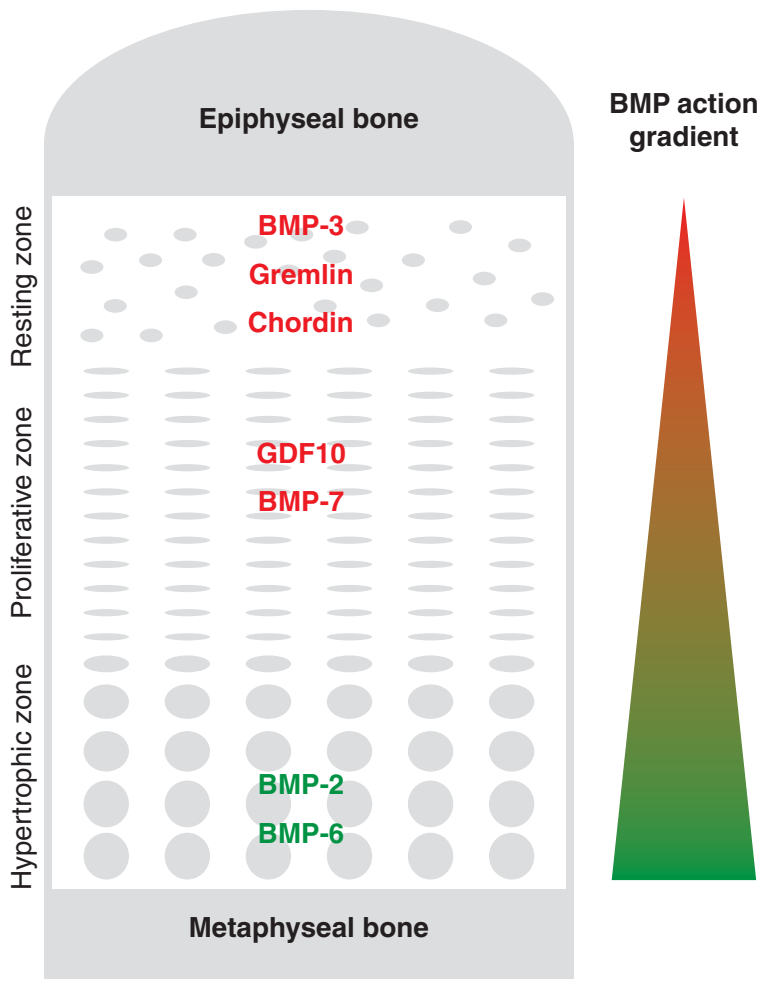

Figure 1

Hypothesized BMP action gradient in the growth plate. Based on microarray and real-time PCR data, BMP agonists (green) and antagonists (red) are expressed primarily in the hypertrophic zone and resting zone respectively. These findings are indicative of a BMP signaling gradient across the growth plate that may be important for spatial control of chondrocyte differentiation within the growth plate.

signaling pathway in that combined loss of regulatory Smad1 and Smad5 in mice causes a severe skeletal dysplasia with impaired proliferation and hypertrophic differentiation (Retting et al. 2009). Although this review focuses on the function of the postnatal growth plate, it is important to recognize that BMP signaling affects embryonic development of the cartilaginous skeleton and thus genetic manipulations in mice may have combined embryonic and postnatal effects.

In addition to BMPs, other paracrine systems also appear to form gradients across the growth plate. Of these, the best studied one involves PTHrP. In the embryonic skeleton, PTHrP is secreted by periarticular chondrocytes of long bones (Kronenberg 2003). PTHrP diffuses across the growth cartilage maintaining chondrocytes in the proliferative state (Hirai et al. 2011). Cells more distant from the source of PTHrP undergo hypertrophic differentiation. The prehypertrophic and hypertrophic chondrocytes then secrete $\mathrm{IHH}$, which positively regulates PTHrP production and also has independent effects on chondrocyte differentiation. More recent evidence has indicated that the IHH-PTHrP system is maintained in the postnatal growth plate, but that the PTHrP source shifts to the resting zone (Koziel et al. 2005, Chau et al. 2011, Hirai et al. 2011).

\section{Genome-wide association studies provide insights into the regulation of the human growth plate}

A recent large meta-analysis of genome-wide association (GWA) studies identified at least 180 loci that influence adult height (Lango et al. 2010). Some of the genes within these loci probably affect height through endocrine mechanisms, such as GH1, which encodes GH, and GHSR, which encodes the GH secretagogue receptor. However, other genes probably affect height through a direct, local effect on the growth plate, such as ACAN, which encodes aggrecan, a critical proteoglycan component of the cartilage matrix. Thus, GWA studies of height have the potential to provide important insights into the molecular pathways regulating the human growth plate.

However, one challenge in the analysis of GWA data is identification the causative gene(s) at each position. At most positions, there are multiple genes that are sufficiently close to account for the linkage to adult stature, and thus additional information is needed to determine which of these genes modulates height and which are merely located close to the causative genes. We therefore used a mouse knockout phenotype database and human disease databases to identify genes within the GWA loci that are probably required for normal growth plate function. We also used expression microarray studies of mouse and rat growth plate to identify genes that have higher expression in growth plate cartilage than in other tissues, genes that are spatially regulated across different zones in the growth plate and/or genes that are temporally regulated in the growth plate during postnatal life, as growth plate function declines.

The combined phenotype-expression-GWA analysis implicated 78 genes in human growth plate function (Lui et al. 2012). Of these, some were already known to function in the human growth plate because human mutations affect the growth plate. In addition, many of the implicated genes participate in molecular pathways that have previously been implicated in the regulation of growth plate chondrocyte proliferation and differentiation in the mouse, such as the IHH-PTHrP system (GLI2, IHH, HHIP, PTCH1, and PTHLH lie within GWA loci), BMP/TGF superfamily signaling (TGFB2, BMP6, LTBP3, NOG, BMP2, and GDF5), C-type natriuretic peptide signaling (NPPC, $P R K G 2$, and NPR3), GH-IGF1 signaling (IGF2BP2, IGF2BP3, and IGF1R),

Published by Bioscientifica Ltd 
and FGF signaling (FGF18). This analysis indicates that these pathways are important not only in the mouse but also in the human growth plate.

In addition, the method implicates many genes not previously known to regulate either the mouse or human growth plate (Lui et al. 2012). For example, the analysis implicates IGF2BP2 and IGF2BP3 based on presence in the GWA loci and expression patterns in the growth plate. These mRNA-binding proteins have previously been implicated in mRNA localization, turnover, and translational control (Christiansen et al. 2009), and mRNA targets include IGF2, H19, c-Myc, $\beta$-actin $(A C T B)$ and GDF1. Although neither IGF2BP2 nor IGF2BP3 has a recognized mouse or human phenotype, targeted ablation of the third member of the gene family, IGF2BP1, impairs bone growth and advances mineralization (Hansen et al. 2004). Thus, the data indicate that this family of proteins regulates growth plate chondrogenesis in both mice and humans.

\section{Loss-of-function mutations of CNP impair and gain-of-function mutations stimulate bone growth}

One interesting pathway implicated by the combined microarray-GWA analysis and by previous studies is C-type natriuretic peptide (CNP or NPPC) signaling (Lui et al. 2012). CNP belongs to a family of three natriuretic peptides, with ANP and BNP being the other two members (Potter et al. 2006). Unlike the other two members, CNP does not stimulate 'natriuresis' at physiological concentrations. Instead, CNP is found at high concentrations in cartilage (Hagiwara et al. 1994) and functions primarily as a local cartilage growth factor to stimulate growth plate chondrocytes (Pejchalova et al. 2007). Interestingly, homozygous loss-of-function mutations of the CNP receptor, natriuretic peptide receptor B (NPRB or NPR2), which is also highly expressed in the growth plate, cause acromesomelic dysplasia type Maroteaux in humans (Bartels et al. 2004), while heterozygous mutations of NPR2 are associated with short stature (Olney et al. 2006, Vasques et al. 2013). Conversely, activating mutations of NPR2 (Miura et al. 2012, Hannema et al. 2013) and overexpression of NPPC (Agoston et al. 2007) in humans both cause overgrowth disorders. These growth phenotypes have been replicated in knockout and transgenic mice, with $N p p c$ or Npr2 knockout causing severely shortened bones (Chusho et al. 2001, Tsuji \& Kunieda 2005) and transgenic expression of activated Npr2 causing increased bone length (Miura et al. 2012). At the cellular level, CNP stimulates chondrocyte proliferation, chondrocyte hypertrophy, and cartilage matrix production (Mericq et al. 2000, Agoston et al. 2007). At the molecular level, CNP inhibits the ERK and p38 MAPK pathways (Ozasa et al. 2005), therefore counteracting the growth-inhibitory downstream signaling of FGFs in the growth plate (Yasoda et al. 2004), which will be discussed in the next section. Owing to its potent effect on offsetting FGF signaling, the use of CNP in treating achondroplasia $(\mathrm{ACH})$ caused by activating mutation of FGF receptor 3 (FGFR3) is under active investigation. It is currently unclear whether all the growth-stimulating effects of CNP on chondrocytes are dependent on FGF signaling.

In addition to $\mathrm{CNP}$, a related peptide, brain natriuretic peptide (BNP), also has been implicated in growth plate regulation. There is evidence that BNP is transcriptionally regulated by the transcription factor SHOX (Marchini et al. 2007). As SHOX deficiency underlies the growth plate dysfunction in Leri-Weill, Langer mesomelic dysplasia, and Turner's syndromes, the findings indicate that decreased NPPB expression may play a role in the pathogenesis of these disorders.

\section{Elucidating the role of FGFs in growth plate}

FGF signaling is important for growth plate development, as mutations in various FGFR genes can lead to skeletal disease in humans (Chen \& Deng 2005). Results from various in in vivo studies indicate that FGFR1 and FGFR3 signaling are growth-inhibiting, while FGFR2 signaling is growth-promoting. Cartilage-specific (Col2a1-Cre) inactivation of $F g f r 1$ in mice showed a transient increase in height of the hypertrophic zone, and delayed terminal differentiation of hypertrophic chondrocytes (Jacob et al. 2006). However, an increase in adult body length has not been reported. In contrast, inactivation of $F g f r 2$ in the mesenchymal condensations (Dermo1-cre), which affects both the osteoblast and chondrocyte lineages, resulted in mice with skeletal dwarfism (Yu et al. 2003), indicating a growth-promoting effect of FGFR2 signaling. Clinically, FGFR3 signaling is perhaps most relevant to growth plate development, as gain-of-function mutations of FGFR3 in humans cause $\mathrm{ACH}$, hypochondroplasia, and thanatophoric dysplasia (Rousseau et al. 1994, Shiang et al. 1994, Foldynova-Trantirkova et al. 2012).

Consistently, transgenic mice with activated Fgfr3 in the growth plate show reduced chondrocyte proliferation, decreased numbers of hypertrophic chondrocytes, and decreased height of the hypertrophic zone (Chen et al. 1999), while Fgfr3 knockout mice showed increased

Published by Bioscientifica Ltd 
chondrocyte proliferation, increased height of the hypertrophic zone, and increased skeletal growth (Eswarakumar $\&$ Schlessinger 2007).

Several signaling pathways downstream of FGFR3 activation have been elucidated, including the phosphoinositide 3-kinase-AKT pathway (Priore et al. 2006, Ulici et al. 2010), the ERK and p38 MAPK pathway (Krejci et al. 2008, Matsushita et al. 2009), and the STAT pathway (Li et al. 1999). These advancements in our understanding of the FGFR3 signaling pathway have contributed to the ongoing development of therapeutics for $\mathrm{ACH}$. For example, growth-plate-specific overexpression of CNP (Col2a1-Nppc) or administration of a CNP analog has been shown to counteract FGF-induced MAPK activation and rescue the growth phenotype of ACH mice (Yasoda et al. 2004, Lorget et al. 2012). Other recently described potential therapeutics for ACH include meclizine, an antihistaminic drug that promotes chondrocyte proliferation (Matsushita et al. 2013); and a soluble form of human FGFR3 (sFGFR3) that acts as a decoy receptor to interfere with FGF binding and signaling (Garcia et al. 2013).

Expression studies in rodents have provided clues about the physiological ligands for FGFRs in the growth plate. In growth plates of 1-week-old rats, only Fgf2, Fgf7, $F g f 18$, and $F g f 22$ expression were detectable by real-time PCR (Lazarus et al. 2007), whereas expression was far higher in the perichondrium adjacent to the growth plate, particularly for $F g f 1, F g f 2, F g f 6, F g f 7, F g f 9$, and $F g f 18$ (Lazarus et al. 2007). In human fetal growth plate, expression of FGF1, FGF2, FGF5, FGF8-FGF14, FGF16$F G F 19$, and FGF21 were detected at the mRNA level and FGF1, FGF2, FGF17, and FGF19 at the protein level (Krejci et al. 2007). Functional studies in mice indicate signaling by FGF9 and FGF18 both contribute to growth plate development. Knockout mouse models of $F g f 9$ (Hung et al. 2007) and Fgf18 (Liu et al. 2002) indicate that both Fgf9 and $F g f 18$ promote chondrocyte proliferation during early development of the growth plate, but then function to inhibit chondrocyte proliferation and promote hypertrophic differentiation at later stages of development.

An interesting crosstalk between FGF signaling and GH-IGF1 signaling in the growth plate has recently been discovered that primarily involves FGF21 (Inagaki et al. 2008). FGF21 is a part of a subfamily of FGFs (other members include FGF15, FGF19 and FGF23) that lack the FGF heparin-binding domain (Kharitonenkov et al. 2005), and therefore can act both locally in a paracrine fashion and diffuse from the tissue of synthesis to act as an endocrine factor. FGF21 can activate FGFR1 and FGFR3 (Suzuki et al. 2008), both of which elicit growth-inhibitory signaling as discussed earlier. Consistently, transgenic mice overexpressing $F g f 21$ exhibit reduced bone growth, and interestingly, hepatic GH insensitivity (Inagaki et al. 2008).

FGF21 expression does not seem to be required for normal development of the growth plate, as $F g f 21$ knockout mice showed no significant difference in body weight and body length as compared with WT mice (Kubicky et al. 2012). However, mounting evidence indicates that FGF21 plays an important role in fasting-induced growth inhibition (Fig. 2). It is well established that reduced caloric intake in mammals causes reduced skeletal growth and hepatic GH insensitivity, which is partly attributed to decreased GH receptor (GHR) expression in the liver (Bornfeldt et al. 1989, Straus \& Takemoto 1990). Numerous studies have shown that FGF21 expression is induced by fasting (Galman et al. 2008). Interestingly, when WT and Fgf21 knockout mice were placed under food restriction, Fgf21 knockout mice showed significantly greater linear growth and growth plate thickness when compared with WT mice, indicating that the growth suppression induced by fasting is elicited by $F \& f 21$ (Kubicky et al. 2012). Most importantly, many of the molecular changes induced by fasting, including

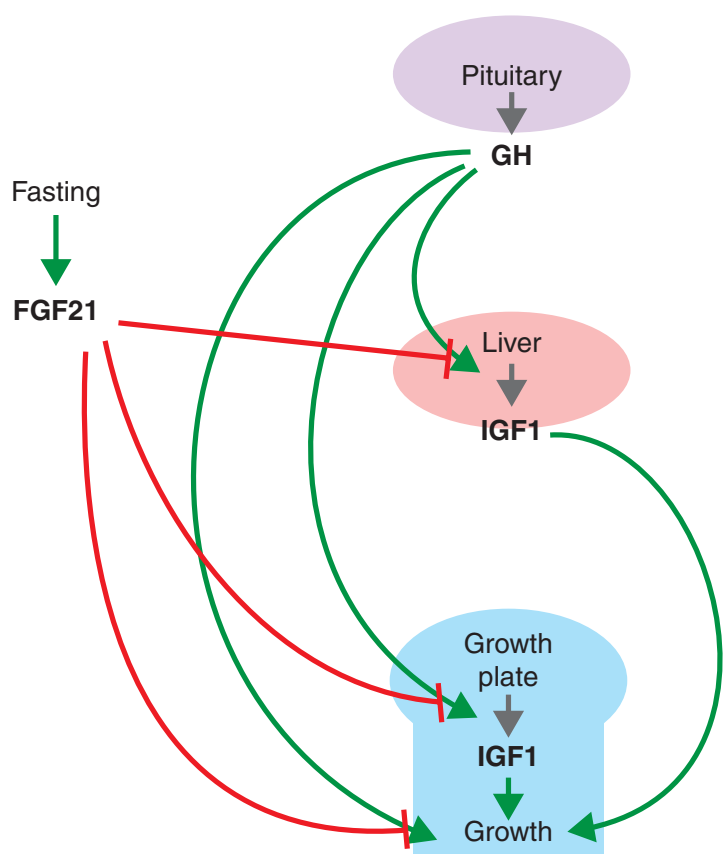

Figure 2

Proposed role of FGF21 in fasting-induced growth inhibition. Green arrows, stimulation; red blunt-ended arrows, inhibition; and gray arrows, production. Evidence indicates that fasting-induced FGF21 inhibits $\mathrm{GH}$-induced IGF1 production in the liver, as well as the local effects of GH (IGF1-dependent and IGF1-independent) at the growth plate. 
decreased hepatic GH sensitivity and decreased GHR and IGF1 expression in the growth plate, were corrected by Fgf21 deletion (Kubicky et al. 2012). More recently, results from in vitro studies using cultured growth plate chondrocytes have indicated that FGF21 may inhibit bone growth by directly suppressing chondrogenesis and GH action locally at the growth plate (Wu et al. 2012, 2013). Whether FGF21 mediates the effects of malnutrition on childhood growth in humans is less clear. Circulating FGF21 levels in humans appear to be less responsive to fasting than those in rodents and are actually elevated in obese humans (Woo et al. 2013).

\section{Modulation of the GH/IGF1 axis by suppressor of cytokine signaling 2}

The importance of GH and IGF1 in stimulating longitudinal growth has long been established. GH excess caused by pituitary adenomas in childhood can lead to gigantism. Conversely, GH deficiency or GH insensitivity caused by mutations in the GHR or signaling pathways markedly impairs postnatal growth (Rosenfeld et al. 2007). Patients with untreated isolated GH deficiency have an average final height standard deviation scores of -4.7 (range: -6.1 to -3.9 ) (Wit et al. 1996). Interestingly, GH has no apparent role in fetal growth, despite the presence of its receptor (GHR) in embryos (Garcia-Aragon et al. 1992). Experimental ablation of the pituitary in animals, or mutations of GHR that affect GH actions in both mice and humans have no significant effect on prenatal growth (Laron et al. 1993, Lupu et al. 2001). In contrast, IGF1 is important for both fetal and postnatal growth, as indicated by the observations that mutations of IGF1 or $I G F 1 R$, the gene encoding its receptor, in humans lead to intrauterine (Abuzzahab et al. 2003, Fang et al. 2012) and postnatal (Baker et al. 1993) growth retardation.

GH affects the growth plate through several mechanisms. Some stimulatory effects are mediated through circulating IGF1, as evidenced by the observation that combined deficiency in the acid-labile subunit and liver-specific deficiency of IGF1 modestly decreases longitudinal bone growth in mice (Yakar et al. 2002). However, Col2-driven ablation of IGF1 in mice also decreases linear growth indicating a role for local skeletal IGF1 production in regulating growth plate function (Govoni et al. 2007), although not necessarily from chondrocytes (Parker et al. 2007). Furthermore, mice lacking both GHR and IGF1 have shorter bones than mice lacking only IGF1, indicating that $\mathrm{GH}$, at least at supraphysiological circulating concentrations, has an IGF1-independent effect on bone growth (Lupu et al. 2001).

Much work has been devoted to distinguish between the effects of GH, and excellent reviews on this subject are available elsewhere (Ahmed \& Farquharson 2010, Wit \& Camacho-Hubner 2011) and therefore will not be discussed further. Instead, herein, we highlight some of the recent work that established suppressor of cytokine signaling 2 (SOCS2) as a key modulator of local GH action in the growth plate.

The SOCS family contains eight members, SOCS1SOCS7 and cytokine inducible SH2-containing protein (CISH). SOCS proteins are upregulated in response to cytokine stimulation and can subsequently bind through their SH2 domain to phosphorylated tyrosines in the cytokine receptor-JAK complex to inhibit further cytokine receptor activation. As such, SOCS proteins form part of a classical negative feedback circuit (Krebs \& Hilton 2001). The role of SOCS2 in postnatal growth was demonstrated by the overgrowth phenotype of Socs 2 knockout mice (Metcalf et al. 2000), Socs $2^{-/-}$mice showed increased body length and body weight, and increased GH/IGF1 signaling with wider proliferative and hypertrophic zones in the growth plate (Metcalf et al. 2000, MacRae et al. 2009). Recent evidence has indicated that SOCS2 acts locally at the growth plate to modulate GH signaling. Chondrocytes isolated from Socs $2^{-1-}$ mice showed increased phosphorylation of STATs upon incubation with GH (Pass et al. 2012), while cells overexpressing SOCS2 did not. Similarly, GH was able to stimulate growth in fetal metatarsals isolated from Socs $2^{-/-}$mice, but not that from WT mice (Pass et al. 2012), indicating that local $\mathrm{GH}$ action at the growth plate is negatively regulated by SOCS2. Some evidence indicates such local modulation of GH action is IGF-independent, as the GH-induced Socs $2^{-1-}$ metatarsal bone growth is not accompanied by an increase in $I g f 1$ or $I g f b p 3$ transcript levels and occurred in the presence of an IGF1 receptor inhibitor (NVPAEW541) (Dobie et al. 2013). A role for SOCS2 in human growth is indicated by the identification of SOCS2 at a locus associated with human height variation in GWA studies (Weedon et al. 2008, Lango et al. 2010, Lui et al. 2012). Interestingly, a missense mutation in SOCS2 has been reported (in meeting abstract form) to cause gigantism (Suda et al. 2011).

\section{Summary and future prospects}

The understanding of the paracrine regulation of longitudinal bone growth at the growth plate has advanced

Published by Bioscientifica Ltd 
substantially in recent years. In this brief review, we have focused on some of the recent advances that have been possible due to microdissection, microarray analysis, inducible and tissue-specific gene targeting in mice, GWA studies, and genetic studies of rare diseases. These studies have not only described important biological mechanisms and processes, but also identified many new genes and indicated a promising potential treatment for ACH that is currently being evaluated in human studies. However, many important questions remain to be elucidated. For example, information on how the endocrine system interacts with the paracrine signals to regulate growth plate chondrogenesis is mostly lacking, as well as information on molecular mechanisms for the orientation of proliferative chondrocytes into columns and mechanisms, which cause the proliferation rate and growth rate to slow with age and thus limit the overall size of the skeleton and thus the organism. Continued methodological advancements promise to accelerate progress in our understanding of skeletal development, skeletal growth, and the disorders affecting these processes and will probably yield new therapeutic targets and approaches.

\section{Declaration of interest}

The authors declare that there is no conflict of interest that could be perceived as prejudicing the impartiality of the review.

\section{Funding}

J C L and J B were supported by the Intramural Research Program of the Eunice Kennedy Shriver National Institute of Child Health and Human Development (NICHD), US National Institutes of Health (NIH). O N was supported by an European Society for Paediatric Endocrinology Research Fellowship Grant and grants from the Swedish Research Council (K201299X-21998-01-3), the Swedish Society of Medicine, Her Royal Highness Crown Princess Lovisa's Foundation for Pediatric Care, Wera Ekstrom's Foundation for Pediatric Research, Märta och Gunnar V Philipson's Foundation, Sällskapet Barnavård, Stiftelsen Frimurare Barnhuset i Stockholm, and Karolinska Institutet.

\section{References}

Abad V, Meyers JL, Weise M, Gafni RI, Barnes KM, Nilsson O, Bacher JD \& Baron J 2002 The role of the resting zone in growth plate chondrogenesis. Endocrinology 143 1851-1857. (doi:10.1210/endo.143.5.8776)

Abuzzahab MJ, Schneider A, Goddard A, Grigorescu F, Lautier C, Keller E, Kiess W, Klammt J, Kratzsch J, Osgood D et al. 2003 IGF-I receptor mutations resulting in intrauterine and postnatal growth retardation. New England Journal of Medicine 349 2211-2222. (doi:10.1056/ NEJMoa010107)

Agoston H, Khan S, James CG, Gillespie JR, Serra R, Stanton LA \& Beier F 2007 C-type natriuretic peptide regulates endochondral bone growth through p38 MAP kinase-dependent and -independent pathways. $B M C$ Developmental Biology 7 18. (doi:10.1186/1471-213X-7-18)
Ahmed SF \& Farquharson C 2010 The effect of GH and IGF1 on linear growth and skeletal development and their modulation by SOCS proteins. Journal of Endocrinology 206 249-259. (doi:10.1677/JOE-10-0045)

Baker J, Liu JP, Robertson EJ \& Efstratiadis A 1993 Role of insulin-like growth factors in embryonic and postnatal growth. Cell $\mathbf{7 5} 73-82$. (doi:10.1016/0092-8674(93)90680-O)

Bartels CF, Bukulmez H, Padayatti P, Rhee DK, van Ravenswaaij-Arts C, Pauli RM, Mundlos S, Chitayat D, Shih LY, Al-Gazali LI et al. 2004 Mutations in the transmembrane natriuretic peptide receptor NPR-B impair skeletal growth and cause acromesomelic dysplasia, type Maroteaux. American Journal of Human Genetics 75 27-34. (doi:10.1086/ 422013)

Bornfeldt KE, Arnqvist HJ, Enberg B, Mathews LS \& Norstedt G 1989 Regulation of insulin-like growth factor-I and growth hormone receptor gene expression by diabetes and nutritional state in rat tissues. Journal of Endocrinology 122 651-656. (doi:10.1677/joe.0.1220651)

Chau M, Forcinito P, Andrade AC, Hegde A, Ahn S, Lui JC, Baron J \& Nilsson O 2011 Organization of the Indian hedgehog - parathyroid hormone-related protein system in the postnatal growth plate. Journal of Molecular Endocrinology 47 99-107. (doi:10.1530/JME-10-0177)

Chen L \& Deng CX 2005 Roles of FGF signaling in skeletal development and human genetic diseases. Frontiers in Bioscience 10 1961-1976. (doi:10.2741/1671)

Chen L, Adar R, Yang X, Monsonego EO, Li C, Hauschka PV, Yayon A \& Deng CX 1999 Gly369Cys mutation in mouse FGFR3 causes achondroplasia by affecting both chondrogenesis and osteogenesis. Journal of Clinical Investigation 104 1517-1525. (doi:10.1172/JCI6690)

Christiansen J, Kolte AM, Hansen T \& Nielsen FC 2009 IGF2 mRNA-binding protein 2: biological function and putative role in type 2 diabetes. Journal of Molecular Endocrinology 43 187-195. (doi:10.1677/JME-090016)

Chusho H, Tamura N, Ogawa Y, Yasoda A, Suda M, Miyazawa T, Nakamura K, Nakao K, Kurihara T, Komatsu Y et al. 2001 Dwarfism and early death in mice lacking C-type natriuretic peptide. PNAS 98 4016-4021. (doi:10.1073/pnas.071389098)

De Luca F, Barnes KM, Uyeda JA, De-Levi S, Abad V, Palese T, Mericq V \& Baron J 2001 Regulation of growth plate chondrogenesis by bone morphogenetic protein-2. Endocrinology 142 430-436. (doi:10.1210/ endo.142.1.7901)

Dobie R, MacRae V, Pass C, Jasim S, Ahmed F \& Farquharson C 2013 Increased linear bone growth in SOCS2 knockout mice in response to $\mathrm{GH}$ is independent of systemic or local IGF1. Endocrine abstracts 31 P2. (doi:10.1530/endoabs.31.P2)

Emons J, Chagin AS, Hultenby K, Zhivotovsky B, Wit JM, Karperien M \& Savendahl L 2009 Epiphyseal fusion in the human growth plate does not involve classical apoptosis. Pediatric Research 66 654-659. (doi:10.1203/PDR.0b013e3181beaa8c)

Eswarakumar VP \& Schlessinger J 2007 Skeletal overgrowth is mediated by deficiency in a specific isoform of fibroblast growth factor receptor 3 . PNAS 104 3937-3942. (doi:10.1073/pnas.0700012104)

Fang P, Hi CY, Derr MA, Rosenfeld RG, Hwa V \& Cowell CT 2012 Severe short stature caused by novel compound heterozygous mutations of the insulin-like growth factor 1 receptor (IGF1R). Journal of Clinical Endocrinology and Metabolism 97 E243-E247. (doi:10.1210/jc.2011-2142)

Foldynova-Trantirkova S, Wilcox WR \& Krejci P 2012 Sixteen years and counting: the current understanding of fibroblast growth factor receptor 3 (FGFR3) signaling in skeletal dysplasias. Human Mutation 33 29-41. (doi:10.1002/humu.21636)

Galman C, Lundasen T, Kharitonenkov A, Bina HA, Eriksson M, Hafstrom I, Dahlin M, Amark P, Angelin B \& Rudling M 2008 The circulating metabolic regulator FGF21 is induced by prolonged fasting and PPAR $\alpha$ activation in man. Cell Metabolism 8 169-174. (doi:10.1016/j.cmet. 2008.06.014)

Garcia S, Dirat B, Tognacci T, Rochet N, Mouska X, Bonnafous S, Patouraux S, Tran A, Gual P, Le Marchand-Brustel Y et al. 2013 Postnatal soluble FGFR3 therapy rescues achondroplasia symptoms and restores bone 
growth in mice. Science Translational Medicine 5 203ra124. (doi:10.1126/ scitranslmed.3006247)

Garcia-Aragon J, Lobie PE, Muscat GE, Gobius KS, Norstedt G \& Waters MJ 1992 Prenatal expression of the growth hormone $(\mathrm{GH})$ receptor/ binding protein in the rat: a role for $\mathrm{GH}$ in embryonic and fetal development? Development 114 869-876.

Govoni KE, Lee SK, Chung YS, Behringer RR, Wergedal JE, Baylink DJ \& Mohan S 2007 Disruption of insulin-like growth factor-I expression in type II $\alpha$ I collagen-expressing cells reduces bone length and width in mice. Physiological Genomics 30 354-362. (doi:10.1152/physiolgenomics.00022.2007)

Hagiwara H, Sakaguchi H, Itakura M, Yoshimoto T, Furuya M, Tanaka S \& Hirose S 1994 Autocrine regulation of rat chondrocyte proliferation by natriuretic peptide $\mathrm{C}$ and its receptor, natriuretic peptide receptor-B. Journal of Biological Chemistry 269 10729-10733.

Hannema SE, van Duyvenvoorde HA, Premsler T, Yang RB, Mueller TD, Gassner B, Oberwinkler H, Roelfsema F, Santen GW, Prickett T et al. 2013 An activating mutation in the kinase homology domain of the natriuretic peptide receptor-2 causes extremely tall stature without skeletal deformities. Journal of Clinical Endocrinology and Metabolism 98 E1988-E1998. (doi:10.1210/jc.2013-2358)

Hansen TV, Hammer NA, Nielsen J, Madsen M, Dalbaeck C, Wewer UM, Christiansen J \& Nielsen FC 2004 Dwarfism and impaired gut development in insulin-like growth factor II mRNA-binding protein 1-deficient mice. Molecular and Cellular Biology 24 4448-4464. (doi:10. 1128/MCB.24.10.4448-4464.2004)

Hirai T, Chagin AS, Kobayashi T, Mackem S \& Kronenberg HM 2011 Parathyroid hormone/parathyroid hormone-related protein receptor signaling is required for maintenance of the growth plate in postnatal life. PNAS 108 191-196. (doi:10.1073/pnas.1005011108)

Hung IH, Yu K, Lavine KJ \& Ornitz DM 2007 FGF9 regulates early hypertrophic chondrocyte differentiation and skeletal vascularization in the developing stylopod. Developmental Biology 307 300-313. (doi:10.1016/j.ydbio.2007.04.048)

Inagaki T, Lin VY, Goetz R, Mohammadi M, Mangelsdorf DJ \& Kliewer SA 2008 Inhibition of growth hormone signaling by the fasting-induced hormone FGF21. Cell Metabolism 8 77-83. (doi:10.1016/j.cmet. 2008.05.006)

Jacob AL, Smith C, Partanen J \& Ornitz DM 2006 Fibroblast growth factor receptor 1 signaling in the osteo-chondrogenic cell lineage regulates sequential steps of osteoblast maturation. Developmental Biology 296 315-328. (doi:10.1016/j.ydbio.2006.05.031)

Kharitonenkov A, Shiyanova TL, Koester A, Ford AM, Micanovic R, Galbreath EJ, Sandusky GE, Hammond LJ, Moyers JS, Owens RA et al. 2005 FGF-21 as a novel metabolic regulator. Journal of Clinical Investigation 115 1627-1635. (doi:10.1172/JCI23606)

Kobayashi T, Lyons KM, McMahon AP \& Kronenberg HM 2005 BMP signaling stimulates cellular differentiation at multiple steps during cartilage development. PNAS 102 18023-18027. (doi:10.1073/pnas. 0503617102)

Koziel L, Wuelling M, Schneider S \& Vortkamp A 2005 Gli3 acts as a repressor downstream of Ihh in regulating two distinct steps of chondrocyte differentiation. Development 132 5249-5260. (doi:10.1242/dev.02097)

Krebs DL \& Hilton DJ 2001 SOCS proteins: negative regulators of cytokine signaling. Stem Cells 19 378-387. (doi:10.1634/stemcells. 19-5-378)

Krejci P, Krakow D, Mekikian PB \& Wilcox WR 2007 Fibroblast growth factors $1,2,17$, and 19 are the predominant FGF ligands expressed in human fetal growth plate cartilage. Pediatric Research 61 267-272. (doi:10.1203/pdr.0b013e318030d157)

Krejci P, Salazar L, Goodridge HS, Kashiwada TA, Schibler MJ, Jelinkova P, Thompson LM \& Wilcox WR 2008 STAT1 and STAT3 do not participate in FGF-mediated growth arrest in chondrocytes. Journal of Cell Science 121 272-281. (doi:10.1242/jcs.017160)
Kronenberg HM 2003 Developmental regulation of the growth plate. Nature 423 332-336. (doi:10.1038/nature01657)

Kubicky RA, Wu S, Kharitonenkov A \& De Luca F 2012 Role of fibroblast growth factor 21 (FGF21) in undernutrition-related attenuation of growth in mice. Endocrinology 153 2287-2295. (doi:10.1210/en.2011-1909)

Lango AH, Estrada K, Lettre G, Berndt SI, Weedon MN, Rivadeneira F, Willer CJ, Jackson AU, Vedantam S, Raychaudhuri S et al. 2010 Hundreds of variants clustered in genomic loci and biological pathways affect human height. Nature 467 832-838. (doi:10.1038/nature09410)

Laron Z, Lilos P \& Klinger B 1993 Growth curves for Laron syndrome. Archives of Disease in Childhood 68 768-770. (doi:10.1136/adc.68.6.768)

Lazarus JE, Hegde A, Andrade AC, Nilsson O \& Baron J 2007 Fibroblast growth factor expression in the postnatal growth plate. Bone $\mathbf{4 0}$ 577-586. (doi:10.1016/j.bone.2006.10.013)

Li C, Chen L, Iwata T, Kitagawa M, Fu XY \& Deng CX 1999 A Lys644Glu substitution in fibroblast growth factor receptor 3 (FGFR3) causes dwarfism in mice by activation of STATs and ink4 cell cycle inhibitors Human Molecular Genetics 8 35-44. (doi:10.1093/hmg/8.1.35)

Liu Z, Xu J, Colvin JS \& Ornitz DM 2002 Coordination of chondrogenesis and osteogenesis by fibroblast growth factor 18 . Genes and Development 16 859-869. (doi:10.1101/gad.965602)

Lorget F, Kaci N, Peng J, Benoist-Lasselin C, Mugniery E, Oppeneer T, Wendt DJ, Bell SM, Bullens S, Bunting S et al. 2012 Evaluation of the therapeutic potential of a CNP analog in a Fgfr3 mouse model recapitulating achondroplasia. American Journal of Human Genetics 91 1108-1114. (doi:10.1016/j.ajhg.2012.10.014)

Lui JC, Andrade AC, Forcinito P, Hegde A, Chen W, Baron J \& Nilsson O 2010 Spatial and temporal regulation of gene expression in the mammalian growth plate. Bone 46 1380-1390. (doi:10.1016/j.bone. 2010.01.373)

Lui JC, Nilsson O, Chan Y, Palmer CD, Andrade AC, Hirschhorn JN \& Baron J 2012 Synthesizing genome-wide association studies and expression microarray reveals novel genes that act in the human growth plate to modulate height. Human Molecular Genetics 21 5193-5201. (doi:10.1093/hmg/dds347)

Lupu F, Terwilliger JD, Lee K, Segre GV \& Efstratiadis A 2001 Roles of growth hormone and insulin-like growth factor 1 in mouse postnatal growth. Developmental Biology 229 141-162. (doi:10.1006/dbio.2000.9975)

MacRae VE, Horvat S, Pells SC, Dale H, Collinson RS, Pitsillides AA, Ahmed SF \& Farquharson C 2009 Increased bone mass, altered trabecular architecture and modified growth plate organization in the growing skeleton of SOCS2 deficient mice. Journal of Cellular Physiology 218 276-284. (doi:10.1002/jcp.21593)

Marchini A, Hacker B, Marttila T, Hesse V, Emons J, Weiss B, Karperien M \& Rappold G 2007 BNP is a transcriptional target of the short stature homeobox gene SHOX. Human Molecular Genetics 16 3081-3087. (doi:10.1093/hmg/ddm266)

Matsushita T, Wilcox WR, Chan YY, Kawanami A, Bukulmez H, Balmes G, Krejci P, Mekikian PB, Otani K, Yamaura I et al. 2009 FGFR3 promotes synchondrosis closure and fusion of ossification centers through the MAPK pathway. Human Molecular Genetics 18 227-240. (doi:10.1093/ hmg/ddn339)

Matsushita M, Kitoh H, Ohkawara B, Mishima K, Kaneko H, Ito M, Masuda A, Ishiguro N \& Ohno K 2013 Meclozine facilitates proliferation and differentiation of chondrocytes by attenuating abnormally activated FGFR3 signaling in achondroplasia. PLOS ONE 8 e81569. (doi:10.1371/ journal.pone.0081569)

Mericq V, Uyeda JA, Barnes KM, De Luca F \& Baron J 2000 Regulation of fetal rat bone growth by C-type natriuretic peptide and cGMP. Pediatric Research 47 189-193. (doi:10.1203/00006450-200002000-00007)

Metcalf D, Greenhalgh CJ, Viney E, Willson TA, Starr R, Nicola NA, Hilton DJ \& Alexander WS 2000 Gigantism in mice lacking suppressor of cytokine signalling-2. Nature 405 1069-1073. (doi:10.1038/35016611)

Miura K, Namba N, Fujiwara M, Ohata Y, Ishida H, Kitaoka T, Kubota T, Hirai H, Higuchi C, Tsumaki N et al. 2012 An overgrowth disorder associated with excessive production of cGMP due to a gain-of-function

Published by Bioscientifica Ltd 
mutation of the natriuretic peptide receptor 2 gene. PLOS ONE 7 e42180. (doi:10.1371/journal.pone.0042180)

Nilsson O, Parker EA, Hegde A, Chau M, Barnes KM \& Baron J 2007 Gradients in bone morphogenetic protein-related gene expression across the growth plate. Journal of Endocrinology 193 75-84. (doi:10.1677/joe.1.07099)

Olney RC, Bukulmez H, Bartels CF, Prickett TC, Espiner EA, Potter LR \& Warman ML 2006 Heterozygous mutations in natriuretic peptide receptor-B (NPR2) are associated with short stature. Journal of Clinical Endocrinology and Metabolism 91 1229-1232. (doi:10.1210/ jc.2005-1949)

Ozasa A, Komatsu Y, Yasoda A, Miura M, Sakuma Y, Nakatsuru Y, Arai H, Itoh N \& Nakao K 2005 Complementary antagonistic actions between C-type natriuretic peptide and the MAPK pathway through FGFR-3 in ATDC5 cells. Bone 36 1056-1064. (doi:10.1016/j.bone.2005.03.006)

Parker EA, Hegde A, Buckley M, Barnes KM, Baron J \& Nilsson O 2007 Spatial and temporal regulation of GH-IGF-related gene expression in growth plate cartilage. Journal of Endocrinology 194 31-40. (doi:10.1677/ JOE-07-0012)

Pass C, MacRae VE, Huesa C, Faisal AS \& Farquharson C 2012 SOCS2 is the critical regulator of $\mathrm{GH}$ action in murine growth plate chondrogenesis. Journal of Bone and Mineral Research 27 1055-1066. (doi:10.1002/ jbmr.1544)

Pejchalova K, Krejci P \& Wilcox WR 2007 C-natriuretic peptide: an important regulator of cartilage. Molecular Genetics and Metabolism 92 210-215. (doi:10.1016/j.ymgme.2007.06.014)

Potter LR, Abbey-Hosch S \& Dickey DM 2006 Natriuretic peptides, their receptors, and cyclic guanosine monophosphate-dependent signaling functions. Endocrine Reviews 27 47-72. (doi:10.1210/er.2005-0014)

Priore R, Dailey L \& Basilico C 2006 Downregulation of Akt activity contributes to the growth arrest induced by FGF in chondrocytes. Journal of Cellular Physiology 207 800-808. (doi:10.1002/jcp.20620)

Retting KN, Song B, Yoon BS \& Lyons KM 2009 BMP canonical Smad signaling through Smad1 and Smad5 is required for endochondral bone formation. Development 136 1093-1104. (doi:10.1242/dev.029926)

Rosenfeld RG, Belgorosky A, Camacho-Hubner C, Savage MO, Wit JM \& Hwa V 2007 Defects in growth hormone receptor signaling. Trends in Endocrinology and Metabolism 18 134-141. (doi:10.1016/j.tem. 2007.03.004)

Rousseau F, Bonaventure J, Legeai-Mallet L, Pelet A, Rozet JM, Maroteaux P, Le MM \& Munnich A 1994 Mutations in the gene encoding fibroblast growth factor receptor-3 in achondroplasia. Nature 371 252-254. (doi:10.1038/371252a0)

Shiang R, Thompson LM, Zhu YZ, Church DM, Fielder TJ, Bocian M, Winokur ST \& Wasmuth JJ 1994 Mutations in the transmembrane domain of FGFR3 cause the most common genetic form of dwarfism, achondroplasia. Cell 78 335-342. (doi:10.1016/0092-8674(94)90302-6)

Shu B, Zhang M, Xie R, Wang M, Jin H, Hou W, Tang D, Harris SE, Mishina Y, O'Keefe RJ et al. 2011 BMP2, but not BMP4, is crucial for chondrocyte proliferation and maturation during endochondral bone development. Journal of Cell Science 124 3428-3440. (doi:10.1242/jcs.083659)

Straus DS \& Takemoto CD 1990 Effect of fasting on insulin-like growth factor-I (IGF-I) and growth hormone receptor mRNA levels and IGF-I gene transcription in rat liver. Molecular Endocrinology 4 91-100. (doi:10.1210/mend-4-1-91)

Suda K, Iguchi G, Yamamoto M, Handayaningsih AE, Nishizawa H, Takahashi M, Okimura Y, Kaji H, Chihara Y \& Takahashi Y 2011 A case of gigantism associated with a missense mutation in the SOCS2 gene. Endocrine Society Annual Meeting 2011. OR36-1.

Suzuki M, Uehara Y, Motomura-Matsuzaka K, Oki J, Koyama Y, Kimura M, Asada M, Komi-Kuramochi A, Oka S \& Imamura T $2008 \beta$ Klotho is required for fibroblast growth factor (FGF) 21 signaling through FGF receptor (FGFR) 1c and FGFR3c. Molecular Endocrinology 22 1006-1014. (doi:10.1210/me.2007-0313)

Tsuji T \& Kunieda T 2005 A loss-of-function mutation in natriuretic peptide receptor 2 (Npr2) gene is responsible for disproportionate dwarfism in cn/cn mouse. Journal of Biological Chemistry 280 14288-14292. (doi:10.1074/jbc.C500024200)

Ulici V, James CG, Hoenselaar KD \& Beier F 2010 Regulation of gene expression by PI3K in mouse growth plate chondrocytes. PLOS ONE 5 e8866. (doi:10.1371/journal.pone.0008866)

Vasques GA, Amano N, Docko AJ, Funari MF, Quedas EP, Nishi MY, Arnhold IJ, Hasegawa T \& Jorge AA 2013 Heterozygous mutations in natriuretic peptide receptor-B (NPR2) gene as a cause of short stature in patients initially classified as idiopathic short stature. Journal of Clinical Endocrinology and Metabolism 98 E1636-E1644. (doi:10.1210/jc. 2013-2142)

Warman ML, Cormier-Daire V, Hall C, Krakow D, Lachman R, LeMerrer M, Mortier G, Mundlos S, Nishimura G, Rimoin DL et al. 2011 Nosology and classification of genetic skeletal disorders: 2010 revision. American Journal of Medical Genetics. Part A 155A 943-968. (doi:10.1002/ ajmg.a.33909)

Weedon MN, Lango H, Lindgren CM, Wallace C, Evans DM, Mangino M, Freathy RM, Perry JR, Stevens S, Hall AS et al. 2008 Genome-wide association analysis identifies 20 loci that influence adult height. Nature Genetics 40 575-583. (doi:10.1038/ng.121)

Wit JM \& Camacho-Hubner C 2011 Endocrine regulation of longitudinal bone growth. Endocrine Development 21 30-41. (doi:10.1159/ 000328119)

Wit JM, Kamp GA \& Rikken B 1996 Spontaneous growth and response to growth hormone treatment in children with growth hormone deficiency and idiopathic short stature. Pediatric Research 39 295-302. (doi:10.1203/00006450-199602000-00018)

Woo YC, Xu A, Wang Y \& Lam KS 2013 Fibroblast growth factor 21 as an emerging metabolic regulator: clinical perspectives. Clinical Endocrinology 78 489-496. (doi:10.1111/cen.12095)

Wu S, Levenson A, Kharitonenkov A \& De Luca F 2012 Fibroblast growth factor 21 (FGF21) inhibits chondrocyte function and growth hormone action directly at the growth plate. Journal of Biological Chemistry $\mathbf{2 8 7}$ 26060-26067. (doi:10.1074/jbc.M112.343707)

Wu S, Grunwald T, Kharitonenkov A, Dam J, Jockers R \& De Luca F 2013 Increased expression of fibroblast growth factor 21 (FGF21) during chronic undernutrition causes growth hormone insensitivity in chondrocytes by inducing leptin receptor overlapping transcript (LEPROT) and leptin receptor overlapping transcript-like 1 (LEPROTL1) expression. Journal of Biological Chemistry 288 27375-27383. (doi:10. 1074/jbc.M113.462218)

Yakar S, Rosen CJ, Beamer WG, Ackert-Bicknell CL, Wu Y, Liu JL, Ooi GT, Setser J, Frystyk J, Boisclair YR et al. 2002 Circulating levels of IGF-1 directly regulate bone growth and density. Journal of Clinical Investigation 110 771-781. (doi:10.1172/JCI0215463)

Yasoda A, Komatsu Y, Chusho H, Miyazawa T, Ozasa A, Miura M, Kurihara T, Rogi T, Tanaka S, Suda M et al. 2004 Overexpression of CNP in chondrocytes rescues achondroplasia through a MAPK-dependent pathway. Nature Medicine 10 80-86. (doi:10.1038/nm971)

Yoon BS, Pogue R, Ovchinnikov DA, Yoshii I, Mishina Y, Behringer RR \& Lyons KM 2006 BMPs regulate multiple aspects of growth-plate chondrogenesis through opposing actions on FGF pathways. Development 133 4667-4678. (doi:10.1242/dev.02680)

Yu K, Xu J, Liu Z, Sosic D, Shao J, Olson EN, Towler DA \& Ornitz DM 2003 Conditional inactivation of FGF receptor 2 reveals an essential role for FGF signaling in the regulation of osteoblast function and bone growth Development 130 3063-3074. (doi:10.1242/dev.00491)

Received in final form 1 April 2014

Accepted 8 April 2014

Accepted Preprint published online 16 April 2014 http://jme.endocrinology-journals.org DOI: 10.1530/JME-14-0022 (c) 2014 Society for Endocrinology Printed in Great Britain
Published by Bioscientifica Ltd 